\title{
Output of peritoneal cells during peritoneal dialysis
}

\author{
OMAR FAKHRI, HAMID AL-MONDHIRY, USAMA N. RIFAAT, \\ MOHAMMAD ALI KHALIL, AND ADIL MAHDI AL-RAWI \\ From the Departments of Medicine and Surgery, College of Medicine, Baghdad, Iraq
}

SUMMARY Peritoneal dialysis provides a good source for the collection of macrophages. Six patients with chronic renal failure undergoing peritoneal dialysis for the first time were studied, and maximum cell egress, mostly macrophages, occurred at $24-48$ hours and diminished after 48 hours.

Collection of monocytes from peripheral blood is a cumbersome procedure and the yield is low. Human macrophages, together with other white cells, were obtained in large quantities from peritoneal dialysis fluid of patients undergoing dialysis for renal failure and were used therapeutically to combat infections in patients with uncontrolled leukaemia, who were no longer responding to antibiotics. The transfusion of peritoneal cells had no obvious side effects (Fakhri et al., 1976a), and earlier in vitro experiments (Fakhri et al., 1976b) suggested that macrophages lack the immunogens that generate the mixed lymphocyte reaction (lymphocyte-determined LD antigens). Furthermore, macrophages $\left(T_{\frac{1}{2}}=71\right.$ hours; Whitelaw, 1972) can enjoy much longer life than neutrophils $\left(\mathrm{T}_{\frac{1}{2}}=6\right.$ hours) and might thereby be more beneficial. The number of lymphocytes and other white cells present with macrophages in the dose of peritoneal cells given was initially too small to cause any side effects, but such cells should be first irradiated with 1500 rads to prevent any subsequent risk of graft-versus-host disease in immunologically depressed recipients.

The number of peritoneal cells and the percentage of macrophages in them varied with time after dialysis. In this paper we present a study of the peritoneal cells removed by dialysis. Such information may be a useful guideline for those intending to use the macrophages therapeutically, or as a substitute for white cell transfusions, especially in centres where leucopheresis units are not available.

\section{Material and methods}

Patients with chronic renal failure, who required

Received for publication 1 December 1977 peritoneal dialysis as part of their medical management, were chosen for this study. Those with acute superadded problems, for example, altered level of consciousness, infection, or other complications necessitating prolonged intensive dialysis, were excluded. The data reported in this study were collected from six patients whose condition was stable enough to allow electively timed dialysis and predialysis investigations.

The patients were dialysed on three successive days at a rate of six litres per day using standard techniques (dialysis solution A-see Appendixwas used in all six patients). The dialysate was collected in polyvinyl chloride (PVC) blood collection bags containing acid citrate dextrose (ACD). Each day's collection was then pooled into a plastic container and the total volume was measured. A representative sample of $30 \mathrm{ml}$ was centrifuged in a plastic tube at $200 \mathrm{~g}$ for 15 minutes at $4^{\circ} \mathrm{C}$. The pellet was then resuspended in $1 \mathrm{ml}$ of saline and counted in a haemocytometer. The total daily output of the cells was calculated, and smears were prepared, stained with Leishman stain, and shown to be morphologically normal. Duplicate differential cell counts were performed, each counting 200 cells. Samples of the leucocytes recovered were studied by a stimulated nitro-blue tetrazolium test and by a candida-killing test (Lehrer and Cline, 1969) and found to have normal phagocytic function. A blood sample was taken from each patient for white cell count before, during, and after conclusion of dialysis. No significant change in the blood picture was noted. In a few patients dialysis and collection of cells continued on the fourth day.

\section{Results}

The Table shows a summary of the results for the 
Table Cell output during three days of peritoneal dialysis

\begin{tabular}{|c|c|c|c|c|c|c|c|c|c|c|c|c|}
\hline \multirow[t]{2}{*}{ Patient } & \multicolumn{4}{|l|}{ First day } & \multicolumn{4}{|l|}{ Second day } & \multicolumn{4}{|l|}{ Third day } \\
\hline & $\begin{array}{l}\text { Total no. of } \\
\text { cells } \times 10^{\circ}\end{array}$ & $N$ & $L$ & $M$ & $\begin{array}{l}\text { Total no. of } \\
\text { cells } \times 10^{\circ}\end{array}$ & $N$ & $\boldsymbol{L}$ & $M$ & $\begin{array}{l}\text { Total no. of } \\
\text { cells } \times 10^{6}\end{array}$ & $N$ & $L$ & $M$ \\
\hline $\begin{array}{l}\text { JT } \\
\text { RT } \\
\text { TR } \\
\text { FH } \\
\text { LM } \\
\text { SH }\end{array}$ & $\begin{array}{r}125 \\
50 \\
60 \\
75 \\
50 \\
450\end{array}$ & $\begin{array}{c}12 \cdot 5 \\
14 \\
6 \\
9 \\
4 \\
50\end{array}$ & $\begin{array}{r}75 \\
12 \\
36 \\
45 \\
12 \\
266\end{array}$ & $\begin{array}{r}37 \cdot 5 \\
24 \\
18 \\
21 \\
34 \\
134\end{array}$ & $\begin{array}{r}1500 \\
400 \\
400 \\
1050 \\
1500 \\
2000\end{array}$ & $\begin{array}{r}30 \\
44 \\
140 \\
63 \\
35 \\
80\end{array}$ & $\begin{array}{r}285 \\
140 \\
40 \\
231 \\
200 \\
30\end{array}$ & $\begin{array}{r}1185 \\
216 \\
220 \\
756 \\
1165 \\
1620\end{array}$ & $\begin{array}{l}225 \\
600 \\
150 \\
125 \\
500 \\
900\end{array}$ & $\begin{array}{r}54 \\
120 \\
9 \\
4 \\
80 \\
135\end{array}$ & $\begin{array}{r}26 \\
120 \\
36 \\
30 \\
40 \\
117\end{array}$ & $\begin{array}{r}145 \\
360 \\
105 \\
91 \\
380 \\
648\end{array}$ \\
\hline
\end{tabular}

first three days of dialysis. On the first day of dialysis the total number of cells was low and the macrophages were generally below $50 \%$. On the second day, the total number of cells increased sharply (5-15 times on the first day) with increased numbers of macrophages. On the third day of dialysis the total number of cells dropped sharply, but the proportion of macrophages remained as high as on the second day, or was even higher. The drop in the cell output was not shown if the patients were not dialysed on the second day. Most of the cells appeared in the first 2-3 litres of the dialysis fluid, and the sixth litre of fluid contained few cells. On the fourth day of dialysis cell egress was very small (less than 50 million), and we thought it was unnecessary to continue the studies beyond the third day even though the dialysis was continued in some patients.

\section{Discussion}

The patients selected for this study were all young or middle-aged and had no problems other than chronic renal failure. It was thought they would give a high yield of cells. They were known to be negative for serum hepatitis B antigen and antibody, but if used for transfusion it would be wise also to know their status with regard to cytomegalovirus, for example, IgM antibody titre. We observed that patients who had secondary infections were shown to give a lower yield of cells, possibly due to the diversion of white cells into other sites, perhaps sites of infection. A considerable number of uraemic patients were shown to have a secondary infection (mainly of the chest and urinary tract), which could be the result of depressed leucocyte functions due to uraemia, and they were not considered for this study. Also the patients chosen were those who did not have a very high blood urea (below $50 \mathrm{mmol} / 1$ $(300 \mathrm{mg} / 100 \mathrm{ml}))$ so that their condition did not necessitate continuous dialysis over a long period of time. They were dialysed for short periods over many days, thus allowing time for the cells to repopulate the peritoneum.
During the first day the total output of cells wasक low, presumably representing the cells available in the mobile phase in the peritoneum. On the second day the number of cells was increased considerably. and the percentage of macrophages increased toof These cells are presumably from the stationary phased in the peritoneum as well as from the circulating blood due to peritoneal irritation.

On the third day the number of cells fell, possibly due to the exhaustion of the cells from such sources $\vec{e}$ and on the fourth day they fell even further. The exhaustion of such potentially effective macrophages could make the patient more prone to develop infection and peritonitis, so we would not encourage collection beyond two days and would encourage the return of the patient's own cells to their own peritoneal cavity when dialysis has to continue foP more than four days.

The output from the second day of peritoneaP dialysis would be the best choice for therapeutie purposes because of the high yield of cells and the. high percentage of macrophages. The macrophages are long-lived $\left(\mathrm{T}_{\frac{1}{2}}=71\right.$ hours; Whitelaw, 1972): Their effectiveness is enhanced some 200 times in the presence of antibodies (Fakhri et al., 1973), and their demonstrated ability to combat infections (Fakhri et al., 1976a) might suggest that they were circulating and functioning normally in the un? related recipients.

We thank Professor J. R. Hobbs, Westminster Hospital, for help with the manuscript.

\section{References}

Fakhri, O., Al-Mondhiry, H., Rifaat, U., and Khalil, M. A. (1976a). Therapeutic use of peritoneal cellso (Letter). Lancet, 1, 1244-1245.

Fakhri, O., McLaughlin, H., and Hobbs, J. R. (1973)尽 $7 \mathrm{~s}$ anti-tumour antibodies and activated $\mathrm{Fc}$ in macro $\frac{\mathrm{D}}{\mathrm{D}}$ phage tumour cells interaction. European Journal of Cancer, 9, 19-23.

Fakhri, O., Mawle, A., and Hobbs, J. R. (1976b) 
Transfusion of macrophages between LD-incompatible subjects? (Letter). Lancet, 1, 94.

Lehrer, R. I., and Cline, M. J. (1969). Leucocyte myeloperoxidase deficiency and disseminated candidiasis: the role of myeloperoxidase in resistance to candida infection. Journal of Clinical Investigation, 48, 14781488.

Whitelaw, D. M. (1972). Observations on human monocyte kinetics after pulse labeling. Cell Tissue Kinetics, 5, 311-317.

Requests for reprints to: Dr Omar Fakhri, c/o Professor J. R. Hobbs, Department of Chemical Pathology, Page Street Wing, Westminster Medical School, 17 Page Street, London SW1P 2AR.
Appendix

FORMULA OF SOLUTION A FOR PERITONEAL DIALYSIS

$\mathrm{Na} \quad=140 \mathrm{mEq} / \mathrm{l}(140 \mathrm{mmol} / \mathrm{l})$

$\mathrm{K}=4 \mathrm{mEq} / 1(4 \mathrm{mmol} / \mathrm{l})$

$\mathrm{Ca}=4.5 \mathrm{mEq} / 1(1.1 \mathrm{mmol} / \mathrm{l})$

$\mathrm{Mg}=1.5 \mathrm{mEq} / 1(0.6 \mathrm{mmol} / \mathrm{l})$

Lactate $=45 \mathrm{mEq} / 1(5.0 \mathrm{mmol} / \mathrm{l})$

Chloride $=105 \mathrm{mEq} / \mathrm{l}(\mathrm{mmol} / \mathrm{l})$

Glucose $=1.5 \%$

\section{Reports and Bulletins prepared by the Association of Clinical Biochemists}

The following reports and bulletins are published by the Association of Clinical Biochemists. They may be obtained from The Publishing Department, British Medical Journal (ACB Technical Bulletins), B.M.A. House, Tavistock Square, London WC1H 9JR. Overseas readers should remit by British Postal or Money Order.

SCIENTIFIC REVIEWS (price $£ 1 \cdot 00 / \$ 2.00$ each)

1 The assessment of thyroid function March 1971 F. V. FLYNN and J. R. HOBBS

2 Renal function tests suitable for clinical practice January 1972 F. L. MTTCHELL, N. VEALL, and R. W. E. WATTS

3 Biochemical tests for the assessment of fetoplacental function May 1975 C. E. WILDE and R. E. OAKEY

4 Test of exocrine pancreatic function March 1977 A. H. GOWENLOCK

TECHNICAL BULLETINS (price $£ 1 \cdot 00 / \$ 2.00$ each)

22 Bilirubin standards and the determination of bilirubin by manual and technicon AutoAnalyzer methods January 1971 BARBARA BILLING, RUTH HASLAM, and N. WALD

23 Interchangeable cells for spectrophotometers and fluorimeters September 1971 S. S. BROWN and A. H. GOWENLOCK

24 Simple tests to detect poisons March 1972 B. w. MEADE et al.

25 Blood gas analysers May 1972 K. DIXON

26 Kits for enzyme activity determination September 1972 S. B. ROSALKI and D. TARLOW

27 Assessment of pumps suitable for incorporation into existing continuous flow analytical systems November 1972 A. FLECK et al.
28 Routine clinical measurements of transferrin in human serum September 1973 K. DIXON

29 Control materials for clinical biochemistry (5th edition) September 1973 J. F. STEVENS

30 Notes on the quality of performance of serum cholesterol assays September 1973 S. S. BROWN

31 Determination of uric acid in blood and in urine July 1974 R. W. E. WATTS

32 A survey of amino acid analysers readily available in the United Kingdom September 1974 J. E. CARLYLE and P. PURKISS

33 Definitions of some words and terms used in automated analysis November 1974 A. FLECK, R. ROBINSON, S. S. BROWN, and J. R. HOBBS

34 Measurement of albumin in the sera of patients January 1975 LINDA SLATER, P. M. CARTER, and J. R. HOBBS

35 Investigation of the validity of temperature correction factors for serum aspartate and alanine transaminases March 1975 s. B. ROSALKI et al.

36 Factors influencing the assay of creatinine November 1975 J. G. H. COOK

37 A survey of enzyme reaction rate analysers readily available in the United Kingdom July 1977 R. A. SAUNDERS and R. F. BURNS

38 Transport of specimens for clinical chemistry analysis November 1977 P. WILDING, J. F. ZILVA, and C. E. WILDE 